Jesús Gamallo Aller*

\title{
EUROPEAN REGIONS AND THE TERRITORIAL INTEGRITY OF EUROPEAN STATES: GALICIA-SPAIN-EUROPE AS A MODEL OF COHESION AND INTEGRATION
}

"United in diversity" is the motto of the European Union.

The European Union (EU) is a union of 27 sovereign Member States. The EU Member States have decided to create a sui generis organization which very much differs from the rest of international organizations that exist or have existed in modern and contemporary history.

The EU is a union of democratic States and, therefore, it respects individual and collective rights. It is a unique organization because it exquisitely respects the rights of minorities and because it does not aspire to unify neither homogenize the different cultures which coexist in Europe. Fortunately, we, Europeans have learnt this hard and bitter lesson from our history. The times of invasions and wars of religion are already over; therefore, the perfect vaccine against our old mistakes is the respect for the diversity inside Europe.

The Treaties, both the EU Treaty and the Treaty on the Functioning of the EU, reiterate this idea of diversity inside the Union. For instance:

"The Union shall respect its rich cultural and linguistic diversity, and shall ensure that Europe's cultural heritage is safeguarded and enhanced." (Article 3.3, in fine, EUT).

"The Union shall contribute to the development of quality education by encouraging cooperation between Member States and, if necessary, by supporting and supplementing their action, while fully respecting the responsibility of the Member States for the content of teaching and the organisation of education systems and their cultural and linguistic diversity." (Article 165.1 TFUE).

"The Union shall contribute to the flowering of the cultures of the Member States, while respecting their national and regional diversity and at the same time bringing the common cultural heritage to the fore." (Article 167.1 TFUE).

\footnotetext{
* Director General for International and EU Affairs Xunta de Galicia.
} 
"The Union shall take cultural aspects into account in its action under other provisions of the Treaties, in particular in order to respect and to promote the diversity of its cultures." (Article 167.4 TFUE).

"The Council shall also act unanimously for the negotiation and conclusion of agreements: a) in the field of trade in cultural and audiovisual services, where these agreements risk prejudicing the Union's cultural and linguistic diversity" (Article 207 TFUE).

However, the text which consecrates this constitutional EU principle of respect to the diversity is in the Charter of Fundamental Rights, which proclaims: "The Union contributes to the preservation and to the development of these common values while respecting the diversity of the cultures and traditions of the peoples of Europe as well as the national identities of the Member States and the organisation of their public authorities at national, regional and local levels; (Third Paragraph of his Preamble).

"The Union shall respect cultural, religious and linguistic diversity." (Article 22 of the Charter).

And, indeed, we can take into account article 55.2 of the EUT, which establishes: "This Treaty may also be translated into any other languages as determined by Member States among those which, in accordance with their constitutional order, enjoy official status in all or part of their territory. A certified copy of such translations shall be provided by the Member States concerned to be deposited in the archives of the Council."

If now we focus on the juridical and political diversity which is often inherent to the cultural diversity inside the Union and its Member States, the respect to the socalled diversity is quite obvious:

"The Union shall respect the equality of Member States before the Treaties as well as their national identities, inherent in their fundamental structures, political and constitutional, inclusive of regional and local self-government. It shall respect their essential State functions, including ensuring the territorial integrity of the State, maintaining law and order and safeguarding national security. In particular, national security remains the sole responsibility of each Member State. (...)." (Article 4.2 EUT).

"Under the principle of subsidiarity, in areas which do not fall within its exclusive competence, the Union shall act only if and in so far as the objectives of the proposed action cannot be sufficiently achieved by the Member States, either at central level or at regional and local level, but can rather, by reason of the scale or effects of the proposed action, be better achieved at Union level..." (Article 5.3, first paragraph, EUT). 
"In formulating and implementing the Union's agriculture, fisheries, transport, internal market, research and technological development and space policies, the Union and the Member States shall, since animals are sentient beings, pay full regard to the welfare requirements of animals, while respecting the legislative or administrative provisions and customs of the Member States relating in particular to religious rites, cultural traditions and regional heritage." (Article 13 TFUE).

In consequence, the EU defends its regional diversity, creating ad hoc a specific Committee, the Committee of the Regions (article 305 to 307 of the TFUE). However this does not contradict, in any way, the perfect compatibility of the EU, which is a Union of States, with the respect and defense of the territorial integrity of States, as article 4.2 of the TUE establishes, since the Union "shall respect the equality of Member States before the Treaties as well as their national identities, inherent in their fundamental structures, political and constitutional, inclusive of regional and local self-government. It shall respect their essential State functions, including ensuring the territorial integrity of the State, maintaining law and order and safeguarding national security. In particular, national security remains the sole responsibility of each Member State."

Therefore, the misleading interpretations of those who want to legitimate the traumatic fracture of a EU Member State in the own peculiarities of EU are unfruitful and deceptive. Those who wish to divide a European State which wishes to become a EU Member have to achieve the division before the adhesion.

The European Communities were created in order to end up with the dance of borders which dyed in blood our history. The analysis of the evolution of the political maps of Europe, from the Low Middle Ages to the end of World War II, confirms that, without the European Union, we would still be Suffering from the basic instincts of populism and the most aggressive nationalism. Except for Portugal and Spain, which have kept the most stable borders in Europe, the territorial alteration of borders has been a source of instability. The game of alliances and counterweights used to break a fragile and costly balance of power.

The European Communities or the EU have never witnessed a rupture or a secession from a Member State. On the contrary, the highest precedent of a territorial mutation was featured by Germany, which incorporated the Länder of the extinct Democratic Republic of Germany, with the consent of the remaining States of the then European Communities. The unification of Germany clearly established that the new German borders would be intangible, eradicating any temptation based in cultural or historical peculiarities. The case of Greenland can only be considered an inappropriate anecdote, as shown by article 204 of the TFUE:

"The provisions of Articles 198 to 203 shall apply to Greenland, subject to the specific provisions for Greenland set out in the Protocol on special arrangements for Greenland, annexed to the Treaties." 
At present, we are undergoing a momentous period: Europe is losing its demographic potential, its economic weight and its scientific and technological strength. There are other emerging countries which are catching-up Europe from these points of view. Under these circumstances, we should not be disdainful before any secessionist speech. If we follow this path, I am convinced that the EU would become ungovernable. Indeed, its failure in the world-wide scene would be unavoidable.

As Jacques Delors stated, "demography is the safest economic parameter. Europe represented $15 \%$ of the world-wide population at the beginning of the past century; it represents $6 \%$ at present, and it will represent $3 \%$ in 2050." If we add to this a political balkanization and a propagation of the risk of contagion which could shake the intangibility of European borders, the failure of Europe, of its States and regions would be absolute and irremediable. We cannot implement in the $21^{\text {st }}$ century a pattern which was not successful in the 19th century, because that would be considered an anachronism.

Moreover, quoting Leibniz, what is the Monad of Territorial Secession? Where is the hypothetical right to a feverish self-determination? And, over all, why should others suffer from the contagion of the lethal virus which aims to alter borders inside Europe?

Let's take the example of Yugoslavia: the war of the former Yugoslavia is the outcome of insane conflicts between continental powers during the 19th century, as well as the upshot of the Treaty of Versailles, and the result of the peculiarities of the 1945 post war scenario. The destabilizing factor in former Yugoslavia was the absence of democratic structures and, therefore, the disrespect to diversity. It is ironic that those who fought in a fratricide war can live together now inside the more plural European Union.

It is indeed sarcastic that the free movement of people and the prohibition of discrimination based on nationality will be soon feasible inside the old Yugoslavia and will be applied to the same citizens that once separated.

Throughout the long-winded European diversity, Galicia can contribute with solutions to make compatible the defense of the local perspective with the construction of Europe. At present, Europe has to face a wider and closer integration in order to deal with the current economic crisis and the structural changes which would preserve and maintain the 'European way of life'.

In the $9^{\text {th }}$ century, when the grave of the Apostle Saint James was discovered, Galicia became a centre of pilgrimage. At that time, the connection of Galicia with Europe started to expand in a nonstop way.

But the international vocation of Galicia increased during the discovery of America, when the caravel "La Pinta" reached the Galician port of Bayona, on 1st March 1493. 
From that time on, Galicia has assumed that its future is linked to Europe and to America, but always in connection with Spain, as it is a permanent part of Spain. Indeed, Galicia is a part of the current democratic Spain, which belongs to the European Union and is represented by the Crown.

Belonging to Spain and belonging to Europe is not only a historical fact, but it is also a natural fact. It is the way we articulate our condition of being European without renouncing to our condition of Galician. We are the heirs of a culture whose main jewel is its language, matrix of the Portuguese language, extended by America, Africa and several spots of Asia and Oceania. Galicia is the intersection between two world-wide languages, the Spanish and the Portuguese, which together have roughly 800 million speakers.

The Autonomous Community of Galicia has a strong collective personality, unsoiled and differentiated. Galicia belongs to a plural Spain, which participates in the European project by vocation, necessity and destiny. We have taken advantage of the opportunities offered by Europe, both in the field of the Cohesion Policy as well as in the Internal Market. The Galician GDP per capita used to be 55\% of its European equivalent. Now, despite the crisis, the GDP of Galicia is around $90 \%$ of the European GDP. This fact certifies that we have exceptionally moved forward in the convergence path. Moreover, this fact makes Galicia one of the most significant success stories of the EU Regional Policy.

We aim to contribute to Europe's stability, growth, better integration and internal cohesion in order to pave our common horizon. We, Galicians, also aim to guarantee that Europe can increase its international competitiveness and its model of society of welfare. None of these goals would be achieved by means of extreme nationalism, of state or regional basis.

We need more cooperation and solidarity, and we need less confrontation and nationalist selfishness. We need to contribute to articulate a positive-sum game, instead of a negative-sum game, where somebody aspires to improve its position by means of worsening the position of the neighbor. Those who wrap themselves in the flag of the twelve golden stars on a azure background to camouflage their secessionist objectives are enemies of the EU flag.

We advance efforts in a very special Federation, with no precedents neither an equivalent model. The crisis of the euro is turning into an opportunity to build a genuine banking and fiscal union, where solidarity is complemented by a greater responsibility. However, although the EU has a rich practical experience in going beyond the crisis, the EU has no experience in submitting the Union to a structural mutation that could put at risk all the EU building, taking into account the emulation effect and the viral effect which may alter European borders. 


\section{EUROPEAN REGIONS AND THE TERRITORIAL INTEGRITY OF EUROPEAN STATES: GALICIA-SPAIN-EUROPE AS A MODEL OF COHESION AND INTEGRATION}

European Union law provides a sound basis for the international activity of regions. It also creates institutional facilities for it. The Spanish Region of Galicia make use of the possibilities available. Although Galicia possesses a rich history and shows a strong trend of individualization, currently it is a part of democratic Spain, which provides Galicia with an appropriate representation in the European Union. Thus, simultaneously, Galicia belongs to both Spain and Europe. Galicia retains its autonomous identity. The region is, however, in favour of the unity of Spain. In particular, it perceives current conditions as unfavourable for intensification of any steps towards emancipation.

Keywords:

Region, Galicia, European Union 